Check for updates

Cite this: RSC Adv., 2017, 7, 49480

Received 25th August 2017 Accepted 9th October 2017

DOI: 10.1039/c7ra09413b

rsc.li/rsc-advances

\section{Potential use of coconut shell activated carbon as an immobilisation carrier for high conversion of succinic acid from oil palm frond hydrolysate}

\author{
Abdullah Amru Indera Luthfi, ${ }^{2}$ Jamaliah Md Jahim, (iD *b Shuhaida Harun, ${ }^{\text {b }}$ \\ Jian Ping Tan ${ }^{a}$ and Abdul Wahab Mohammad ${ }^{b}$
}

\begin{abstract}
Economical production of succinic acid via bacterial immobilisation offers significant potential to meet the demands of an ever increasing global population. However, insufficient research has been devoted to converting lignocellulosic materials into succinic acid via bacterial immobilisation. In the present work, bacterial immobilisation onto porous supports was investigated using wild-type Actinobacillus succinogenes 130Z. The use of a cost-effective and robust coconut shell activated carbon (CSAC) carrier was compared with kieselguhr, exclay, coal activated carbon, and vermiculite. It was found that the electrokinetic potential exhibited by exclay was the lowest $(-17 \mathrm{mV})$, followed by CSAC $(-16 \mathrm{mV})$. Maximum succinic acid conversion from oil palm frond (OPF) bagasse hydrolysate was reported with $A$. succinogenes immobilised on CSAC, with $23 \%$ improvement over the use of free cells. The highest succinic acid production yielded $40.2 \mathrm{~g} \mathrm{~L}^{-1}$ in batch-mode cultivation. Repeated batch fermentation was performed using CSAC for 5 cycles over $180 \mathrm{~h}$, attaining an average succinic acid concentration of $44.1 \mathrm{~g} \mathrm{~L}^{-1}$, productivity of $1.3 \mathrm{~g} \mathrm{~L}^{-1} \mathrm{~h}^{-1}$ and yield of $0.9 \mathrm{~g} \mathrm{~g}^{-1}$ of OPF bagasse hydrolysate for all batches. Collectively, the results highlight the critical role of coconut shell as a renewable source of a carbon carrier for repeated biosynthesis of succinic acid.
\end{abstract}

\section{Introduction}

The rising prevalence of high-carbon mainstream markets worldwide threatens ecosystems and natural resources. ${ }^{1}$ To lessen the impacts of ecological imbalances, bio-based production of succinic acid has been developed progressively, marking the possible end of the global dominance of petrochemicals. ${ }^{2,3}$ Recently, increasing attention has been devoted to the utilization of renewable resources, such as corn stover, ${ }^{4}$ cassava bagasse, ${ }^{5}$ sugarcane bagasse, ${ }^{6}$ empty fruit bunches, ${ }^{7}$ oak wood, ${ }^{8}$ and oil palm frond ${ }^{9,10}$ in the economical production of succinic acid. ${ }^{\mathbf{1 1}}$

In Malaysia, the annual production of oil palm waste reaches 90 million tonnes (dry basis), more than half of which is accounted for by oil palm frond (OPF) bagasse. Unfortunately, OPF could only find utility as low-value animal feed, or soilmulching fertilizer. ${ }^{12}$ Hence, utilizing OPF waste for succinic acid production is critical to sustainable development, owing to its abundance. ${ }^{\mathbf{1 0}}$

Succinic acid, a high-value molecule of the C4-dicarboxylic acid family, can be biotechnologically synthesized through the

${ }^{a}$ Department of Chemical and Process Engineering, Faculty of Engineering and Built Environment, Universiti Kebangsaan Malaysia, 43600 UKM Bangi, Selangor, Malaysia ${ }^{b}$ Research Centre for Sustainable Process Technology (CESPRO), Faculty of Engineering and Built Environment, Universiti Kebangsaan Malaysia, 43600 UKM Bangi, Selangor, Malaysia. E-mail: jamal@ukm.edu.my; Fax: +60-3-8911-8345; Tel: +60-3-8921-6427 reductive incomplete tricarboxylic acid (TCA) cycle or the glyoxylate shunt. ${ }^{13}$ Accordingly, the potential succinate-producing bacteria currently under commercialization are Mannheimia succiniciproducens (MBEL, KAIST), Actinobacillus succinogenes (Michigan Biotechnology Institute), Escherichia coli (Myriant), Basfia succiniciproducens (Succinity), and Corynebacterium glutamicum (Ajinomoto).11,14 Batch fermentation with a wild-type A. succinogenes $130 \mathrm{Z}$ has been reported to achieve a productivity of $0.8 \mathrm{~g} \mathrm{~L}^{-1} \mathrm{~h}^{-1}$, with the addition of $\mathrm{MgCO}_{3} \cdot{ }^{13}$ In another study using glucose-fed batch fermentation with $A$. succinogenes CGMCC1593, a yield of $0.75 \mathrm{~g} \mathrm{~g}^{-1}$ and a productivity of $1.3 \mathrm{~g} \mathrm{~L}^{-1} \mathrm{~h}^{-1}$ have been reported. ${ }^{15} \mathrm{~A}$ higher volumetric productivity implied lower capital expenses, as it allows a smaller equipment sizing to achieve a desirable capacity. ${ }^{\mathbf{1 6}}$

Further improvement on the production performance of succinic acid has been established through conventional metabolic engineering of ruminal bacteria. However, the lack of sufficiently good genetic tools for A. succinogenes sp. has presented as a bottleneck for efficient bio-based production of succinic acid. ${ }^{\mathbf{1 7 , 1 8}}$ Alternatively, another stream of research has focused on the immobilisation of A. succinogenes sp., due to the well-documented ability of this strain to be naturally selfadhered onto a solid substratum. ${ }^{16,19}$ Entrapment of cells has been reported to exhibit mass-transfer constraints, due to the limited diffusivity of nutrients through the matrix particles. ${ }^{20}$ Thus, immobilised cell systems by adhesion have been 
proposed to not only anchor microorganisms in a favorable environment with minimal mass-transfer resistance, but also promote a high culture density for enhanced substrate utilization. ${ }^{21,22}$ In this regard, important criteria for selection of an excellent sorbent material include, but are not limited to: (i) cost-effective, (ii) inert and non-toxic, (iii) readily up-scalable, (iv) easily operated, (v) chemically/mechanically stable and durable, (vi) highly porous with large specific surface area, and (vii) heat-sterilisable. ${ }^{23,24}$

Coconut shell-based activated carbon (CSAC) are among the most promising sorbent material due to its relatively higher mechanical strength, good abrasion resistance, inherent granular structure, well-developed porosity, and cheaper alternative compared with other similar grades of commercially available activated carbons. ${ }^{25,26}$ The aforementioned characteristics are important for a continuous packed-bed process that has many attractive features, such as the elimination of step to separate the product from the cells and the ease of scale-up under constant operating conditions. ${ }^{27,28}$ As such, CSAC was chosen as a material for immobilisation of A. succinogenes $130 \mathrm{Z}$ due to its excellent natural structure and low ash content. ${ }^{28}$ Previously, CSAC had been successfully adopted for immobilisation of Thermoanaerobacterium thermosaccharolyticum sp. for stable production of biohydrogen, ${ }^{22}$ and Pseudomonas putida sp. for simultaneous biosorption-bioaccumulation of phenol and cyanide. ${ }^{29}$

Therefore, this work aimed to produce succinic acid from the hydrolysate of OPF bagasse i.e. via a straightforward celladhesion technique. This paper attempted to compare the various existing types of immobilisation carriers with the CSAC, in order to demonstrate its potential superiority. Additionally, the physicochemical characteristics of such materials were elucidated herein.

\section{Materials and methods}

\subsection{Chemicals and materials}

Kieselguhr, exclay or expanded clay, coconut shell activated carbon (CSAC), coal activated carbon (CAC), and vermiculite were compared and evaluated for immobilisation study, as these materials are inexpensive, non-toxic, and heat-sterilisable. Kieselguhr, exclay, vermiculite, and CAC were bought from Scienfield Expertise (Selangor, Malaysia), and HCl-treated CSAC was purchased from Concepts Ecotech (Selangor, Malaysia). CSAC was further treated with $6.0 \mathrm{M} \mathrm{HNO}_{3}$ at $100{ }^{\circ} \mathrm{C}$ for $2 \mathrm{~h}$ and was denoted as NA-CSAC. ${ }^{30}$ Enzymes Cellic ${ }^{\circledR}$ CTec2 (activity: 142 FPU per mL) and Cellic ${ }^{\circledR}$ HTec2 (activity: $1129 \mathrm{U} \mathrm{mL}^{-1}$ ) were obtained from Novozymes A/S (Bagsvaerd, Denmark). All other chemicals were of reagent grade, and were bought from either Fisher Scientific (Loughborough, UK) or Ever Gainful Enterprise (Selangor, Malaysia), unless otherwise specified.

\subsection{Microorganism and growth conditions}

A. succinogenes $130 \mathrm{Z}$ DSM 22257 was acquired from German Collection of Microorganisms and Cell Cultures (DSMZ, Brunswick, Germany), and was maintained in cryovials at
$-40{ }^{\circ} \mathrm{C}$ in a $15 \%$ glycerol solution. A. succinogenes was cultivated through an inoculum expansion process in brain heart infusion medium containing brain heart infusion broth $(1.75 \mathrm{wt} \%)$ and peptone $(1.00 \mathrm{wt} \%)$ as well as a $10 \%$ immobilisation carrier. Prior to the immobilisation, each solid support was washed with deionised water, and flared in a muffle furnace at $550{ }^{\circ} \mathrm{C}$ for $15 \mathrm{~min}$ to remove all the organic impurities. ${ }^{31}$

\subsection{Preparation of OPF bagasse hydrolysate}

The raw material adopted in this work was the OPF bagasse from a previous study. ${ }^{9}$ The OPF bagasse was dried, and mechanically milled to a particle size of $2 \mathrm{~mm}$. Prior to enzymatic hydrolysis, the dried OPF bagasse samples were pretreated with $1.2 \mathrm{M}$ sodium hydroxide $(\mathrm{NaOH})$ at $100{ }^{\circ} \mathrm{C}$ for $58 \mathrm{~min}$, followed by autohydrolysis at $121{ }^{\circ} \mathrm{C}$ for $20 \mathrm{~min}$. The pretreated material composition comprised mainly glucan $(62.7 \%)$, xylan $(15.6 \%)$, lignin $(17.1 \%)$ and total extractives (4.1\%). Enzymatic hydrolysis at $6 \%$ glucan loading was performed with Cellic CTec2 (cellulase) loaded aseptically at 30 FPU per $\mathrm{g}$ and also with Cellic HTec2 (hemicellulase) at $50 \mathrm{U}$ per $\mathrm{g}$. The hydrolysate was filtered through four layers of gauze cloth to remove the insoluble solid fraction. Table 1 shows the characteristics of OPF bagasse hydrolysate used in succinic acid fermentation.

\subsection{Succinic acid production}

The fermentation medium was composed of (per liter): $0.2 \mathrm{~g}$ $\mathrm{CaCl}_{2}, 3.0 \mathrm{~g} \mathrm{KH}_{2} \mathrm{PO}_{4}, 1.0 \mathrm{~g} \mathrm{NaCl}, 15.0 \mathrm{~g}$ yeast extract, and $1.0 \mathrm{~g}$ defoamer. $\mathrm{MgCO}_{3}$ at $40 \mathrm{~g} \mathrm{~L}^{-1}$ was added as a $\mathrm{pH}$ regulator and as a source of $\mathrm{CO}_{2}$, and OPF bagasse hydrolysate was incorporated as the main carbon source. ${ }^{32}$ It is noteworthy that the use of $\mathrm{NaOH}$-based pre-treated OPF bagasse hydrolysate in producing succinic acid was demonstrated to be on a par with pure sugars, as it contained minimal amounts of recalcitrant substances. ${ }^{9}$

The exponentially growing immobilised A. succinogenes was then transferred into the medium at $10 \%$ of $300 \mathrm{~mL}$ working volume under sterile condition. Prior to fermentation, the headspace of the vessels was flushed with nitrogen gas for $20 \mathrm{~min}$ to ensure anaerobiosis. Batch fermentation was performed at $37{ }^{\circ} \mathrm{C}, \mathrm{pH} 6.5$, and $200 \mathrm{rpm}$ for $32 \mathrm{~h}$ in a $1.0 \mathrm{~L}$ bioreactor equipped with a Tedlar® PVDF for $\mathrm{CO}_{2}$ retention.

Table 1 The characteristics of OPF bagasse hydrolysate ${ }^{a}$

\begin{tabular}{ll}
\hline Items & Characteristics \\
\hline Color & Whitish yellow liquid \\
pH & $4.76 \pm 0.3$ \\
Hexose: glucose & $54.1 \pm 1.2 \mathrm{~g} \mathrm{~L}^{-1}$ \\
Pentose: xylose & $13.4 \pm 0.7 \mathrm{~g} \mathrm{~L}^{-1}$ \\
Total nitrogen & $158.94 \pm 0.5 \mathrm{mg} \mathrm{L}^{-1}$ \\
Trace element: & $13.37 \pm 1.1 \mathrm{mg} \mathrm{L}^{-1}$ \\
magnesium &
\end{tabular}

${ }^{a}$ Data are duplicates from two independent experiments represented as mean \pm standard deviation. 


\subsection{Cell-recycle repeated batch fermentation}

Repeated batch fermentations for five successive runs were conducted within $180 \mathrm{~h}$ using a fill-and-draw method, comprising repetitive feed and discharge cycles. ${ }^{33}$ Temperature and agitation rates were maintained at $39{ }^{\circ} \mathrm{C}$ and $200 \mathrm{rpm}$, respectively. After each run of the fermentation trial, non-viable cells in suspension were flushed with a sterile $\mathrm{NaCl}(0.9 \mathrm{wt} \%)$ four times. The cells from the previous run were reused, and a fresh medium was added for the fermentation of the subsequent runs. Fermentation samples were periodically taken until a minimum lignocellulose consumption was attained. ${ }^{34}$

\subsection{Analytical methods}

Characterization of the carrier material used in this study was performed using a Physisorption Analyzer (Micromeritics ASAP 2010, Norcross, GA, USA). Both the Brunauer-Emmett-Teller (BET) surface area and pore characteristics were determined using the $\mathrm{N}_{2}$ adsorption/desorption isotherm at $77 \mathrm{~K}$.

The concentration of the immobilised cells on the support was determined based on the weight loss on ignition, known as the volatile suspended solids (VSS) method, as per the American Public Health Association (APHA) protocol. ${ }^{35,36}$ To quantify the extracellular polymeric substances (EPSs) of A. succinogenes, the impregnated carrier was crushed with a pestle (to detach the loosely and tightly bound EPS), and collected for EPS extraction. The EPSs were extracted through the formaldehyde- $\mathrm{NaOH}$ method by Liu and Fang, ${ }^{37}$ in which the samples were treated with $37 \%$ formaldehyde at $4{ }^{\circ} \mathrm{C}$ for $1 \mathrm{~h}$, followed by $1 \mathrm{M} \mathrm{NaOH}$ treatment for $3 \mathrm{~h}$. The EPSs were then characterized using the phenol-sulphuric acid and Bradford methods for the quantification of carbohydrates and proteins, respectively. ${ }^{38,39}$ The presence of the key types of functional groups in the EPSs was verified using a Fourier transform infrared (FTIR) spectroscopy (Nicolet 6700, Waltham, USA) in a direct transmittance mode, via the attenuated total reflectance method. The region recorded was between 4000 and $400 \mathrm{~cm}^{-1}$ with a resolution of $2 \mathrm{~cm}^{-1}$. The electrokinetic characterisation involved the measurement of the zeta potential using a Malvern Zetasizer Nano ZS (ZEN 3600, Worcestershire, UK) with the aid of Dispersion Technology Software (DTS) version 5.02.

The visualization of the immobilised A. succinogenes involved several steps. Upon being fixed with glutaraldehyde $(2.0 \mathrm{wt} \%)$ at $4{ }^{\circ} \mathrm{C}$ overnight, the impregnated CSAC samples were washed with $0.1 \mathrm{M}$ phosphate-buffered saline (PBS). Subsequently, they were subjected to dehydration with $30-100 \%$ ethanol and further drying with a Critical Point Dryer (Leica EM CPD 300, Wetzlar, Germany). This was followed by sputter coating with platinum, and analysis through variable pressure scanning electron microscopy (VPSEM) (LEO 1450VP, Oberkochen, Germany).

The sugars and organic acids were analyzed using highperformance liquid chromatography (UltiMate 3000 LC system, Sunnyvale, CA), equipped with the refractive index detector (RID) set at $40{ }^{\circ} \mathrm{C}$. Rezex ROA-Organic Acid $\mathrm{H}^{+}$column (300 mm $\times 7.8 \mathrm{~mm}$; Phenomenex, USA) was isocratically eluted with $\mathrm{H}_{2} \mathrm{SO}_{4}(2.5 \mathrm{mM})$ at a flow rate of $0.6 \mathrm{~mL} \mathrm{~min}^{-1}{ }^{40}$

\subsection{Determination of fermentation parameters}

During the course of fermentation, the fraction of cells formed per unit time, known as specific growth rate $(\mu)$ was calculated by estimating the ratio of $\ln \left(x_{n+1} / x_{n}\right)$ to the relative difference of time in h, where $x$ is the cells concentration in $\mathrm{g} \mathrm{L}^{-1}$. The subscript $n$ denotes the number of sampling throughout the fermentation. The productivity of succinic acid $\left(R_{\mathrm{P}}\right)$, and the rate of substrate consumption $\left(R_{\mathrm{S}}\right)$ in $\mathrm{g} \mathrm{L}^{-1} \mathrm{~h}^{-1}$ were obtained by determining the slope of succinic acid, and reducing sugar concentrations against the relative difference of fermentation time. Whereas the yield of succinic acid $\left(Y_{\mathrm{P} / \mathrm{S}}\right)$ or cells $\left(Y_{\mathrm{x} / \mathrm{S}}\right)$ was determined as the ratio of its concentration to the relative difference of substrates (i.e., substrates consumption), and was expressed in unit $\mathrm{g} \mathrm{g}^{-1}$.

\section{Results and discussion}

\subsection{Surface area and porosity of carrier materials}

The criteria of specific surface area, total pore volume, and material purity are important factors in determining the proper choice of an immobilisation carrier. Low ash content in a particular material is associated with high purity. ${ }^{22}$ Table 2 outlines the characteristics of carrier materials used in this study. The surface area and pore characteristics of materials determine the extent of adhesion (i.e., cell-surface interaction) and cohesion (i.e., cell-cell interaction). ${ }^{\mathbf{4 1}}$ As shown in Table 2, both coconut shell and coal activated carbon materials had much higher specific surface area and total pore volume, compared to other materials. It is worthy of note that larger pore volume implies higher capacity to hold a substance of interest. ${ }^{42}$

The average pore size of CSAC $(21.2 \AA)$ was much greater than that of CAC (4.5 $\AA$ ) with nearly five-fold difference. In this

Table 2 Characteristics of the materials used for immobilization

\begin{tabular}{|c|c|c|c|c|c|}
\hline Carrier materials & $\begin{array}{l}\text { BET surface area } \\
\left(\mathrm{m}^{2} \mathrm{~g}^{-1}\right)\end{array}$ & $\begin{array}{l}\text { Total pore volume } \\
\left(\mathrm{cm}^{3} \mathrm{~g}^{-1}\right)\end{array}$ & Average pore type & $\begin{array}{l}\text { Moisture } \\
\text { content (\%) }\end{array}$ & $\begin{array}{l}\text { Ash content } \\
(\% \max )\end{array}$ \\
\hline Kieselguhr & 42.17 & 0.18 & Macropore & $<3$ & $<1$ \\
\hline Exclay & 79.04 & 0.06 & Micropore/mesopore & $<3$ & $<1$ \\
\hline CSAC & 846.57 & 0.45 & Micropore/mesopore & $<6$ & $<3$ \\
\hline NA-CSAC & 1058.08 & 0.56 & Micropore/mesopore & $<10$ & $<3$ \\
\hline CAC & 479.49 & 0.30 & Micropore & $<10$ & $<5$ \\
\hline Vermiculite & 5.37 & 0.02 & Mesopore & $<3$ & $<3$ \\
\hline
\end{tabular}


regard, three types of internal pore are associated with sorbent materials, which are: (i) micropore (diameter $<2 \mathrm{~nm}$ ); (ii) mesopore (diameter $=2-50 \mathrm{~nm}$ ), and (iii) macropore (diameter $>50 \mathrm{~nm}) .{ }^{43}$ Such pore types affect the extent of immobilisation based on the size of the target molecule to be adsorbed. However, the macroporous structure may not influence the adsorptivity of a material. ${ }^{22,43}$ For instance, kieselguhr, a form of silica, is known to have a macropore-dominant structure, but is fairly high in the specific surface area. It was hypothesized that a material with high specific surface area would lead to enhanced adsorptivity, as demonstrated by Vichuviwat et al., who demonstrated the superiority of acid-treated zeolite (531 $\left.\mathrm{m}^{2} \mathrm{~g}^{-1}\right)$ over brick $\left(7 \mathrm{~m}^{2} \mathrm{~g}^{-1}\right)$ in cell adsorption. ${ }^{42}$

\subsection{Extracellular polymeric substance and electrokinetic potential of biofilm}

Biofilms and their extracellular polymeric substances (EPSs) have been metaphorically described as the "city of microbes" and the "house of the cells", respectively. ${ }^{44}$ As with many unicellular organisms, A. succinogenes can secrete EPSs to form biofilms under prolonged operations. ${ }^{19,45}$ Typically, the main components in EPSs are proteins and polysaccharides which facilitate in the overall binding process. ${ }^{41}$ Hence, the composition of the EPS fraction of A. succinogenes on different carrier materials is tabulated in Table 3. It was found that proteins are a predominant constituent in the EPSs. Similar observations have been reported for pure cultures of Gram-negative and Gram-positive bacteria: proteins presented as the primary component of the EPS matrix, with polysaccharides being the secondary component. ${ }^{\mathbf{4 6 7}}$ Moreover, the hydrophobic and anionic properties of EPS can be regulated by the extracellular proteins of the cultures.

In general, EPS can be found in any material with high amount of organic substances. Bacterial colonization is governed by the surface characteristics of a material, but the quantity of EPS formed varies depending on the type of microorganisms, the substrate availability (carbon source and other nutrients), different operational condition ( $\mathrm{pH}$, temperature, shear forces and retention time), and age of the

Table 3 Results of total carbohydrate and protein content on different types of the carrier material

\begin{tabular}{llll}
\hline & \multicolumn{2}{l}{$\begin{array}{l}\text { Major EPS constituents }^{a} \\
\left(\% \mathrm{~g} \mathrm{~g}^{-1} \text { VSS }\right)\end{array}$} & \\
\cline { 2 - 3 } Carrier materials & Carbohydrate & Protein & $\begin{array}{l}\text { Ratio protein/ } \\
\text { carbohydrate }\end{array}$ \\
\hline Exclay & $24.9 \pm 0.7$ & $46.0 \pm 0.9$ & 1.8 \\
CSAC & $24.7 \pm 0.1$ & $45.3 \pm 0.5$ & 1.8 \\
Vermiculite & $22.5 \pm 0.6$ & $37.1 \pm 1.1$ & 1.6 \\
CAC & $22.5 \pm 1.3$ & $36.9 \pm 0.8$ & 1.6 \\
Kieselguhr & $21.1 \pm 0.3$ & $35.9 \pm 0.2$ & 1.7 \\
NA-CSAC & $20.6 \pm 0.9$ & $31.0 \pm 1.3$ & 1.5 \\
Free cells & $19.7 \pm 0.7$ & $28.5 \pm 0.4$ & 1.4 \\
a Each value is an average of two parallel replicates and is represented as \\
mean \pm standard deviation.
\end{tabular}
depend on the surface are EPS formed can alter the physicochemical characteristics of the colonized surface which may promote irreversible cell attachment. ${ }^{41}$ As shown in Table 3, exclay is associated with the highest EPS content (70.9\%), followed by CSAC (70.0\%). Unfortunately, NA-CSAC with a very high specific surface area $\left(1058 \mathrm{~m}^{2} \mathrm{~g}^{-1}\right)$ yielded a lower EPS content (51.6\%), compared to other materials. The presence of more acidic functionalities on the surface of nitric acid-treated CSAC reduced the hydrophobicity and adsorptive capacity, in accordance with previous studies. ${ }^{51,52}$ On the other hand, the untreated CSAC has contributed to 1.5-fold the total amount of protein and carbohydrate in free cells. Besides, this study demonstrated that the ratios of proteins to carbohydrates in the EPS fraction ranged from 1.4 to 1.8 for all the tested materials.

Fig. 1 depicts the typical FTIR spectrum of the EPS formed during the bacterial fermentation. A broad $\mathrm{O}-\mathrm{H}$ stretching is observed at approximately $3400 \mathrm{~cm}^{-1} .^{53}$ Moreover, a strong absorption band at approximately $1645 \mathrm{~cm}^{-1}$ was found to be associated with the stretching vibration of $\mathrm{C}(\mathrm{N})=\mathrm{O}$ and $\mathrm{C}-\mathrm{N}+$ $\mathrm{N}-\mathrm{H}$ groups in proteins. ${ }^{41}$ Such groups have been known to act as ligands to divalent cations, thereby stabilizing the biopolymer networks in response to cell immobilisation. ${ }^{53}$ The presence of aromatic structures and unsaturated fatty acid chains could be observed at approximately $695 \mathrm{~cm}^{-1}$ which exhibited the typical structural components in EPS. ${ }^{47}$

EPSs are the naturally self-produced bio-components of microbial origins, which appear to be associated with electrostatic interactions or van der Waals forces between the cells and the charged solid surface. ${ }^{46}$ The net negative charges created between the EPS and the substratum have been one of the wellknown factors affecting microbial immobilisation, and can be assessed through a zeta potential measurement. It has been postulated that a negatively charged surface created by the EPS could affect bacterial adsorption. ${ }^{41}$ Fig. 2 depicts the zeta potentials on different materials used for A. succinogenes

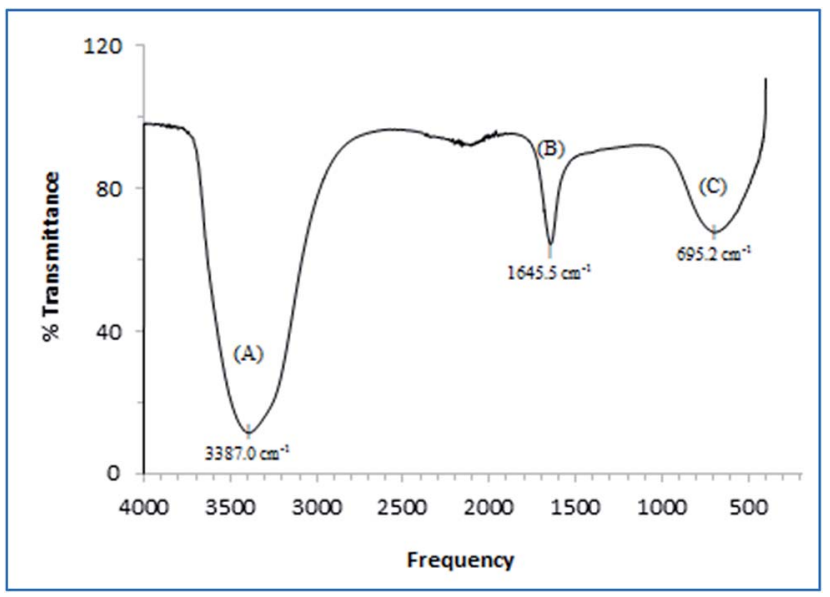

Fig. 1 IR spectra of EPS produced by $A$. succinogenes $130 \mathrm{Z}$ after $32 \mathrm{~h}$ fermentation showing (A) combination of amino and hydroxyl groups, (B) carboxyl groups in proteins, and (C) unsaturated bonds. 


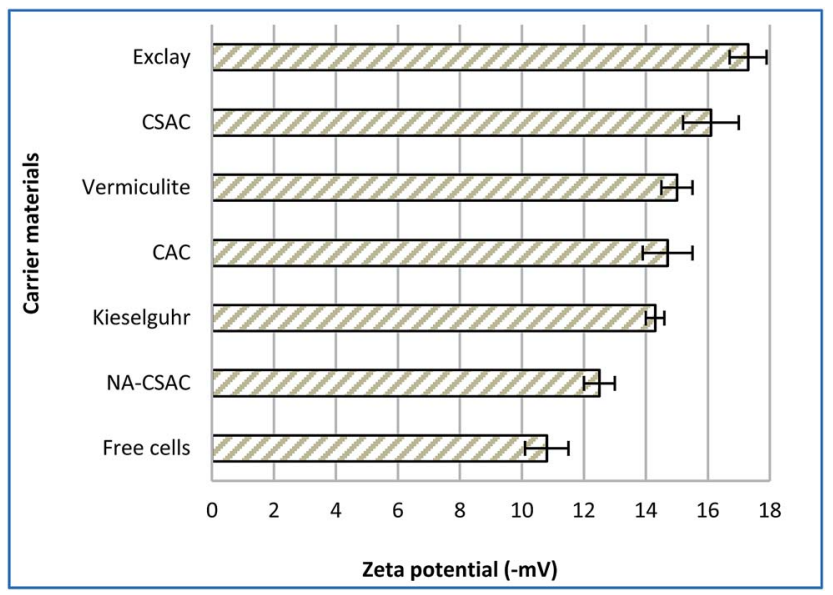

Fig. 2 Comparison of zeta potential of different carrier materials. Expressed in $-\mathrm{mV} \pm \mathrm{SD}$. immobilisation, and on free cells which served as basis of comparison for the current analysis. As seen in Fig. 2, the use of immobilisation carriers has contributed to reduction in zeta potential values. It can be clearly seen that NA-CSAC gave the smallest reduction in zeta potential value (15.7\%), despite its very high specific surface area. It seems reasonable to postulate that this phenomenon might be due to the reduction of the cell surface hydrophobicity which impeded biofilm growth. According to Li et al., ${ }^{51}$ the NA-CSAC had a high oxygencontaining functional groups which tend to block pore entrances towards the hydrophobic compounds and the availability of adsorption sites was limited due to hydration. Thus, NA-CSAC was not suitable for immobilisation of A. succinogenes. The electrokinetic potential was statistically lowest for exclay (two-tailed $t$-test, $P=0.0003$ ) with a zeta potential of $-17 \mathrm{mV}$, followed by CSAC (two-tailed $t$-test, $P=0.0013$ ) with a zeta potential of $-16 \mathrm{mV}$. A higher negativity or reduction in the zeta
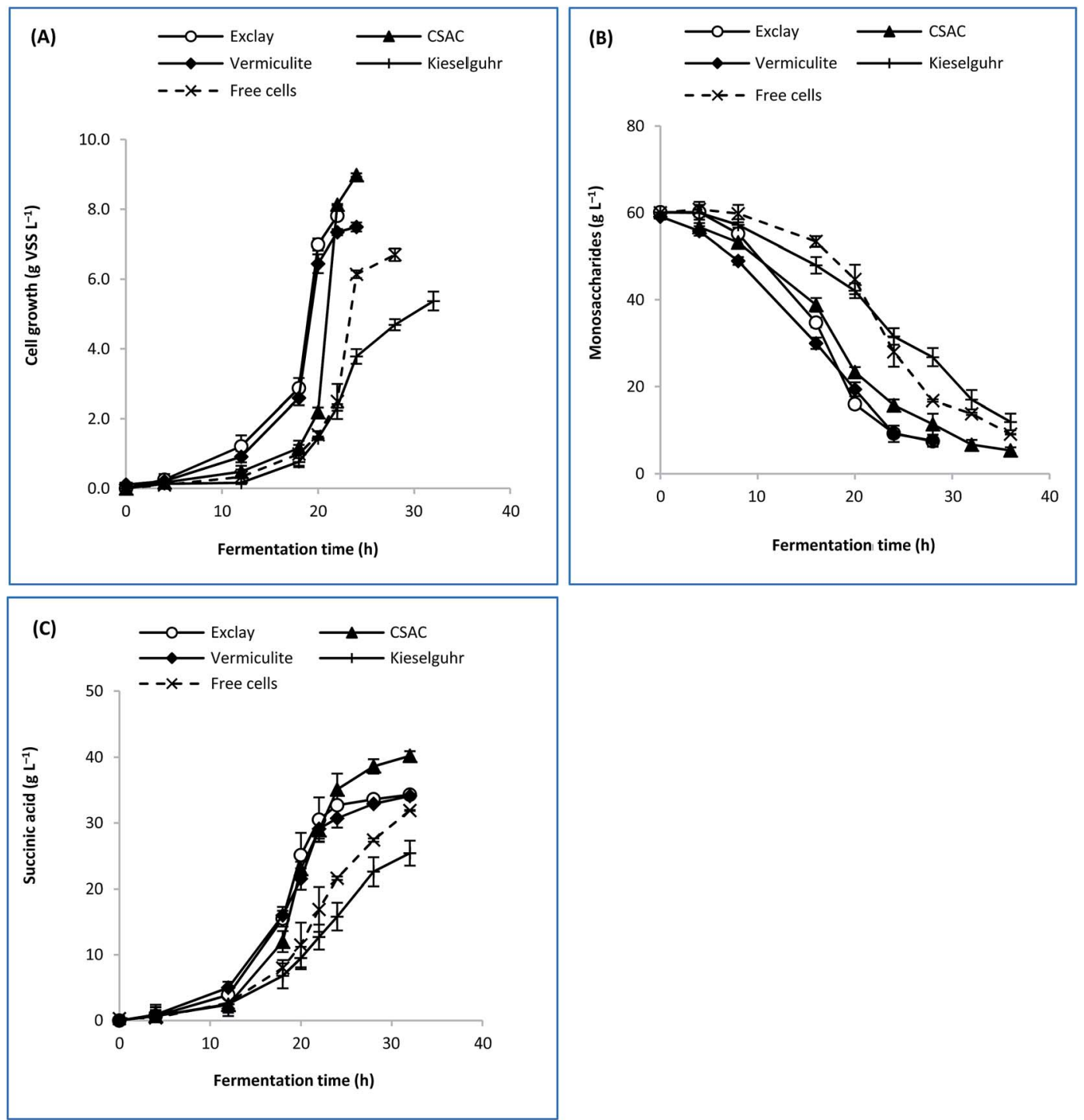

Fig. 3 Time course profile of batch fermentation based on different immobilization carriers showing (A) cell growth, (B) sugar consumption, and (C) succinic acid formation. 
potential has been associated with the reduction in electrostatic repulsion, thus promoting bacterial immobilisation and augmenting the rate of biofilm granulation..$^{54}$

\subsection{Fermentation performance via immobilized $A$. succinogenes}

The rationale for adopting cells immobilization strategy was due to the high cells retention which would lead to better lignocellulose sugars intake. ${ }^{5}$ Hence, enhanced succinic acid production can be attributed to the copious amount of sugars thus consumed. ${ }^{10}$ To ascertain the role of factors such as the specific surface area, porosity, and electrokinetic potential of each carrier material, further experimentation was attempted to elucidate their possible effects on the performance of bacterial fermentation. Despite its high specific surface area, CAC produced fine carbon dust that deteriorated the fermentation broth and caused inconsistent performance in producing succinic acid after some time, which restricted further kinetic studies. Therefore, only exclay, CSAC, vermiculite, and kieselguhr were used as immobilisation carriers in the current analysis.

Fig. 3 depicts the time course profile of sugar consumption, cell growth, and succinic acid formation for immobilised-cell and free-cell fermentations. It is evident that cell growth occurred at relatively high rates $(x>6.0 \mathrm{~g}$ VSS per $\mathrm{L}$ after $20 \mathrm{~h})$ for exclay and vermiculite, in comparison to other materials, as a result of which the substrate was consumed rapidly $\left(R_{\mathrm{S}}=1.1 \mathrm{~g} \mathrm{~L}^{-1} \mathrm{~h}^{-1}\right)$. As for CSAC, the cell growth rate occurred slowly during the first $20 \mathrm{~h}$ (Fig. 3(A)). This phenomenon is probably due to its much bigger surface area, compared to other materials, causing the cells to have a longer adaptation phase to fully occupy the cavities of CSAC. This led to a longer lag phase before moving into exponential succinic acid production phase. At this exponential phase, the biological processes begin to dominate and form stronger bonding between cells. ${ }^{50}$

Concerning the dimension of internal pores, materials which exhibited micro/mesoporous structures performed favourably in fermentation. ${ }^{41,42}$ It was found that cell growth on these carriers were $11.7-34.0 \%$ greater than that obtained from the free cells. Similarly, the productions of succinic acid with immobilised cells were found at $6.8-26.0 \%$ higher than that with the free cells. Therefore, it was suggested that micro/ mesopore-dominant structures of a material played a significant role in immobilizing A. succinogenes. Conversely, kieselguhr exhibited the lowest rate of cell growth $(\mu)$, sugar consumption $\left(R_{\mathrm{S}}\right)$, and succinic acid formation $\left(R_{\mathrm{P}}\right)$. This can be due to its macropore-dominant structure (Table 2) which did not influence the bacterial adsorptivity. Additionally, its inferior performance might have arisen from the shedding of cells from such a support. ${ }^{21}$ Therefore, kieselguhr was not suitable for $A$. succinogenes immobilisation.

Table 4 shows the performance of succinic acid fermentation after $32 \mathrm{~h}$ for immobilised and free cells. Succinic acid was formed as the main product, leaving only acetic and formic acids as the by-products during the anaerobic fermentation. Contrary to these findings, co-production of lactic acid has also been reported with $A$. succinogenes in the presence of oxygen. ${ }^{55}$ As seen in Table 4, CSAC can be considered a promising carrier for immobilisation as it afforded the highest cell concentration $\left(9.0 \mathrm{~g} \mathrm{~L}^{-1}\right)$, which was 1.3-fold greater than that with the free cells. In this regard, the highest formation of succinic acid was $40.2 \mathrm{~g} \mathrm{~L}^{-1}$. The use of CSAC has contributed to $23 \%$ improvement in the conversion of succinic acid from the OPF bagasse hydrolysate $\left(Y_{\mathrm{P} / \mathrm{S}}\right)$ as compared to the free cells. Apart from CSAC, exclay afforded a slightly higher cell concentration $(7.8 \mathrm{~g}$ $\left.\mathrm{L}^{-1}\right)$ than vermiculite $\left(7.5 \mathrm{~g} \mathrm{~L}^{-1}\right)$, leading to a correspondingly small increment in the concentration of succinic acid. The production performance of succinic acid by adopting CSAC is better than exclay because of its much higher specific surface area, more uniform pore distribution and comparable EPS content. The factors of excellent surface area that allows copious capacity for cell retention, and high EPS content which promotes irreversible cell attachment will result in a good succinic acid production performance. ${ }^{42}$ Hence, the extent of cell growth on different porous supports appeared to be directly influenced by a reduced zeta potential and a highly porous structure. $^{41}$

3.3.1 Bacterial observation on CSAC. A. succinogenes $130 \mathrm{Z}$ colonies were observed to grow within the cavities of CSAC after

Table 4 Performance of succinic acid fermentation in batch mode for different carrier materials and free cells ${ }^{a}$

Carrier material

\begin{tabular}{|c|c|c|c|c|c|}
\hline \multirow[b]{2}{*}{ Parameters } & \\
\hline & Exclay & CSAC & Vermiculite & Kieselguhr & Free cells \\
\hline Succinic acid $\left(\mathrm{g} \mathrm{L}^{-1}\right)$ & $34.3 \pm 0.41$ & $40.2 \pm 0.39$ & $34.1 \pm 0.52$ & $27.4 \pm 0.16$ & $31.9 \pm 1.39$ \\
\hline By-products $\left(\mathrm{g} \mathrm{L}^{-1}\right)$ & $13.7 \pm 0.09$ & $5.4 \pm 0.21$ & $12.9 \pm 0.06$ & $6.7 \pm 0.15$ & $8.2 \pm 1.46$ \\
\hline Succinic acid/by-products ratio (\%) & 2.5 & 7.4 & 2.6 & 4.1 & 4.1 \\
\hline Substrate consumption (\%) & 87.6 & 90.5 & 87.5 & 80.1 & 84.8 \\
\hline$x(\mathrm{~g}$ VSS per $\mathrm{L})$ & $7.8 \pm 0.31$ & $9.0 \pm 0.43$ & $7.5 \pm 0.14$ & $5.4 \pm 0.09$ & $6.7 \pm 0.33$ \\
\hline$\mu_{\max }\left(\mathrm{h}^{-1}\right)$ & $0.45 \pm 0.10$ & $0.66 \pm 0.09$ & $0.46 \pm 0.17$ & $0.32 \pm 0.02$ & $0.45 \pm 0.06$ \\
\hline$R_{\mathrm{P}}\left(\mathrm{g} \mathrm{L}^{-1} \mathrm{~h}^{-1}\right)$ & $1.07 \pm 0.13$ & $1.26 \pm 0.07$ & $1.07 \pm 0.09$ & $0.86 \pm 0.06$ & $0.99 \pm 0.14$ \\
\hline$R_{\mathrm{S}}\left(\mathrm{g} \mathrm{L}^{-1} \mathrm{~h}^{-1}\right)$ & $2.17 \pm 0.06$ & $1.62 \pm 0.53$ & $2.08 \pm 0.17$ & $1.28 \pm 0.13$ & $1.54 \pm 0.49$ \\
\hline$Y_{\mathrm{P} / \mathrm{S}}\left(\mathrm{g} \mathrm{g}^{-1}\right)$ & $0.78 \pm 0.29$ & $0.85 \pm 0.22$ & $0.73 \pm 0.28$ & $0.67 \pm 0.16$ & $0.69 \pm 0.10$ \\
\hline$Y_{\mathrm{x} / \mathrm{S}}\left(\mathrm{g} \mathrm{g}^{-1}\right)$ & $0.19 \pm 0.05$ & $0.35 \pm 0.07$ & $0.18 \pm 0.03$ & $0.13 \pm 0.19$ & $0.16 \pm 0.04$ \\
\hline
\end{tabular}

${ }^{a}$ Data are duplicates from two independent experiments represented as mean \pm standard deviation. 


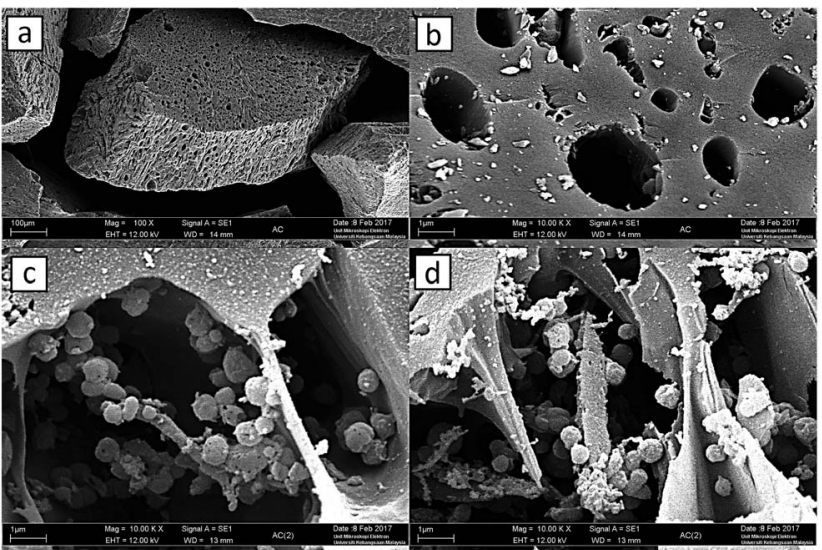

Fig. 4 VPSEM result of (a) a single porous CSAC at a magnification of $100 \times$, (b) close-up view of highly porous, irregular structured CSAC at a magnification of $10000 \times$, (c) and (d) bacterial immobilization on CSAC after batch cultivation at magnifications of $10000 \times$.

batch cultivation of $32 \mathrm{~h}$ and were examined through VPSEM. Fig. 4(a and b) are SEM images of clean or uninhabited CSAC, while Fig. 4(c and d) depict the impregnated CSAC after immobilisation. The images revealed the presence of coccobacilli-shaped $A$. succinogenes cells which were arranged in chains and were interspersed. ${ }^{56}$ This finding was congruent with other studies indicating that $A$. succinogenes could appear in the form of circular, gray, and translucent organisms, with an average size of around $0.63 \mu \mathrm{m} \times 0.63 \mu \mathrm{m} \times 1.21 \mu \mathrm{m} .{ }^{56,57}$ It was also presented that the CSAC had a highly porous structure which permitted the space for cell growth.

\subsection{Trials of repeated batch fermentation}

The repeated batch fermentation was intended to assess the impact of cell immobilisation against product stability and fermentation performance. Fig. 5 depicts the profile of five cycles of repeated batch fermentation with A. succinogenes immobilised on CSAC. The initial sugar concentration of the bagasse hydrolysate was maintained at $60 \mathrm{~g} \mathrm{~L}^{-1}$. It was important to note that during the growth of A. succinogenes at more than $60 \mathrm{~g} \mathrm{~L} \mathrm{~L}^{-1}$ initial hydrolysate sugar, the succinic acid production could be inhibited as demonstrated by a previous study.$^{58}$ In this work, the amount of total nitrogen in the OPF hydrolysate was very low (Table 1), and did not contribute to the production performance of succinic acid.

The remained amount of immobilised cells at the initial phase in batches 2 to 5 was approximately $25-40 \%$ due to the washing with isotonic saline. Nevertheless, this loss does not jeopardize the overall fermentation performance, since the non-viable cells have been removed. It is apparent that the production of succinic acid was consistent in each batch, regardless of the fermentation time. The ratios of succinic acid to by-products increased in batch 2 by approximately $12.0 \%$ and remained stable from batches 3 to 5 . A similar observation was reported by Alexandri et al. who used A. succinogenes immobilised on delignified cellulose. ${ }^{59}$ On the contrary, the formation of formic acid showed considerable reduction possibly due to the minute amounts of formate being utilized for NADH compensation within A. succinogenes cells, which were believed to stimulate the flux of central metabolism towards the less energy-producing succinate pathway. ${ }^{9,60}$

As depicted in Fig. 5, the adaptation phase could only be observed in the first 12 hours for batch 1 . Subsequently, the time to reach the maximum production of succinic acid from batches 2 to 5 was remarkably shortened, indicating that the cells had been well-attuned to their environment. A similar observation has been reported in the literature. ${ }^{5}$ Succinic acid production in each batch was estimated at an average concentration of $44.1 \mathrm{~g} \mathrm{~L}^{-1}$ and a yield of $87 \% \mathrm{~g} \mathrm{~g}^{-1}$, with the

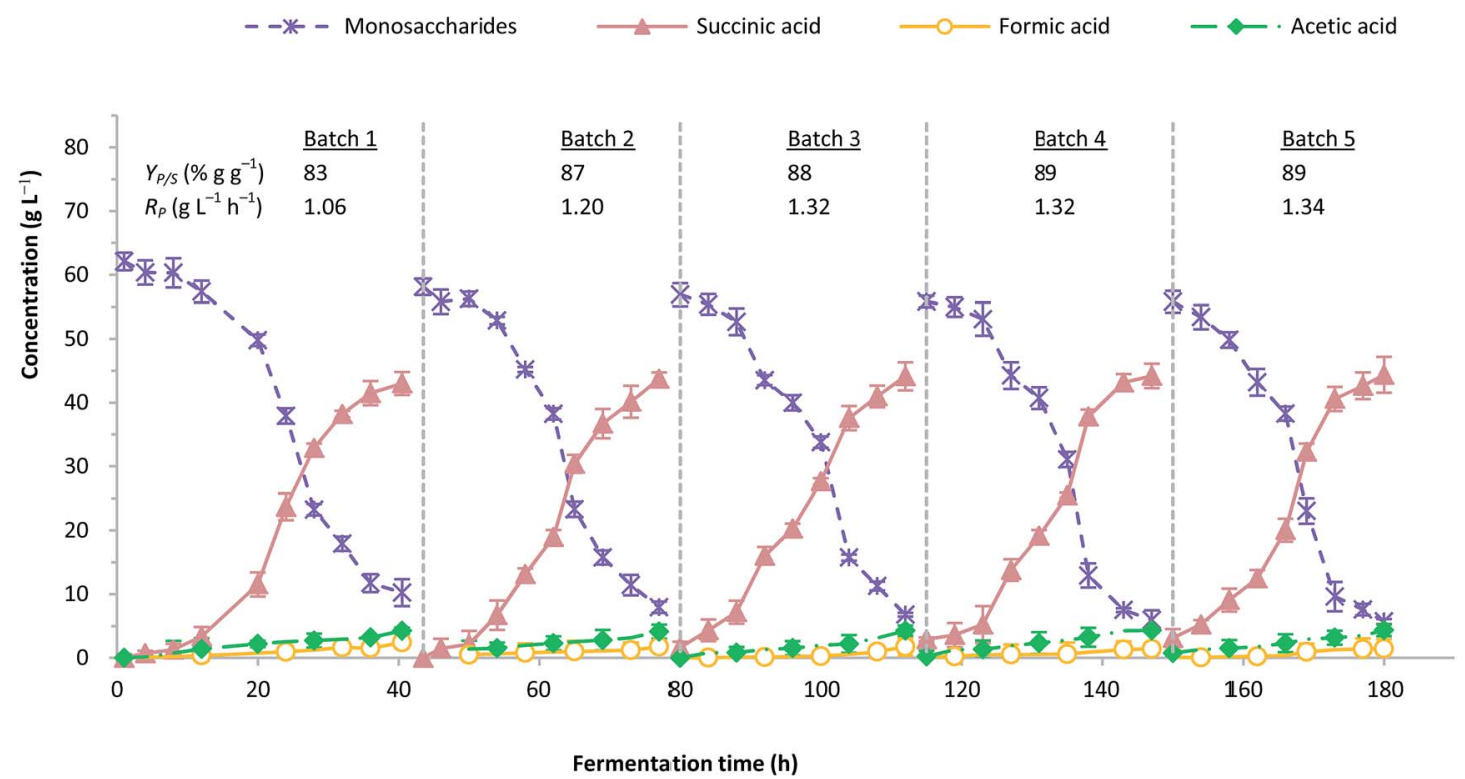

Fig. 5 Profile for five consecutive cycle of repeated batch fermentation with immobilized A. succinogenes on CSAC. 


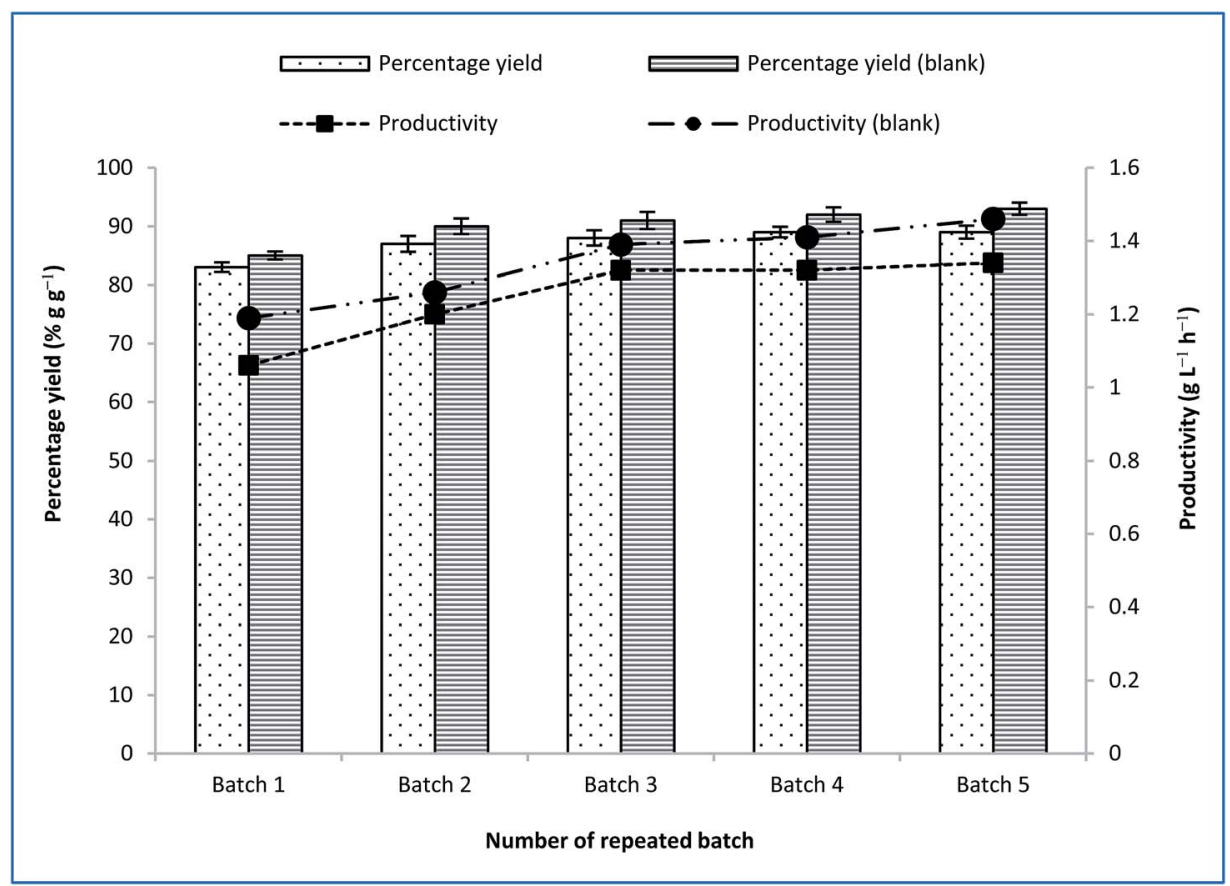

Fig. 6 Final succinic acid yield and productivity at repeated batch fermentation with CSAC-immobilized A. succinogenes using OPF bagasse hydrolysate and synthetic (blank) media.

productivity ranging from 1.0 to $1.3 \mathrm{~g} \mathrm{~L}^{-1} \mathrm{~h}^{-1}$. In order to validate the fermentation result, a synthetic medium which consisted of pure sugars mimicking the composition of OPF bagasse hydrolysate was used as the fermentation blank.

Fig. 6 outlines the final yields of succinic acid and productivity during repeated batch fermentation with CSACimmobilised A. succinogenes using OPF bagasse hydrolysate and synthetic medium. Both the yield of succinic acid and the productivity using the synthetic medium were slightly higher than those obtained using OPF bagasse hydrolysate, which were in the vicinity of $90 \% \mathrm{~g} \mathrm{~g}^{-1}$ and $1.5 \mathrm{~g} \mathrm{~L}^{-1} \mathrm{~h}^{-1}$, respectively. The results, however, ascertained that the use of the inexpensive OPF bagasse could be a useful alternative to commercial pure sugars for bio-based production of succinic acid. To date, the results obtained in this study highlight considerable improvement over existing studies in literature employing bagasse hydrolysate as a carbon source. ${ }^{5,61}$

Table 5 summarizes different immobilisation strategies with different types of succinic acid-producing microorganisms.
Fermentation time was compared to evaluate the durability of materials used for cell immobilisation. In a study by Shi et al., $C$. glutamicum immobilised onto porous polyurethane filler (PPF) was demonstrated to produce an average of $22.5 \mathrm{~g} \mathrm{~L}^{-1}$ succinic acid from $35 \mathrm{~g} \mathrm{~L}^{-1}$ initial sugar of cassava bagasse hydrolysate through five repeated batches. ${ }^{5}$ In another study, Alexandri et al. reported succinic acid production of $64.7 \mathrm{~g} \mathrm{~L}^{-1}$ from $114.6 \mathrm{~g} \mathrm{~L}^{-1}$ sugar consumption with B. succiniciproducens immobilised on alginate beads; the authors, however, also reported the rupture of alginate after the fourth cycle, due to the increasing cell growth and calcium discharge..$^{59}$

Therefore, the use of micro/mesopore-dominant structure of CSAC has been demonstrated to contribute to a remarkable improvement in the fermentative production of succinic acid from OPF bagasse hydrolysate. Incorporating CSAC as the immobilisation carrier could afford high yields and titres of succinic acid within $180 \mathrm{~h}$. In this study, the average sugar consumption attained for all batches was $50.2 \mathrm{~g} \mathrm{~L}^{-1}$, which resulted in an average production of $44.1 \mathrm{~g} \mathrm{~L}^{-1}$ succinic acid.

Table 5 Various immobilization materials and performances on microbial succinic acid production ${ }^{a}$

\begin{tabular}{|c|c|c|c|c|c|c|}
\hline Carrier material & Microorganism & Time (h) & Titer $\left(\mathrm{g} \mathrm{L}^{-1}\right)$ & Yield $\left(\% \mathrm{~g} \mathrm{~g}^{-1}\right)$ & $\begin{array}{l}\text { Productivity } \\
\left(\mathrm{g} \mathrm{L}^{-1} \mathrm{~h}^{-1}\right)\end{array}$ & References \\
\hline Polypropylene & A. succinogenes & $\mathrm{n} / \mathrm{d}$ & 237.2 & 83 & $\mathrm{n} / \mathrm{d}$ & 34 \\
\hline Polysulfone & E. faecalis & 360 & 46.2 & 92 & 9.20 & 62 \\
\hline Agar & A. succinogenes & 40 & 33.6 & 45 & 1.32 & 61 \\
\hline Polyurethane & C. glutamicum & 267 & 22.5 & 65 & 0.42 & 5 \\
\hline
\end{tabular}

\footnotetext{
${ }^{a} \mathrm{n} / \mathrm{d}$ - not detected.
} 


\section{Conclusions}

Our characterization of CSAC revealed that its porosity, surface area, and low electrokinetic potential contribute to its excellent performance in succinic acid fermentation. The use of CSAC was shown to contribute to the reduction of zeta potential value to $-16 \mathrm{mV}$. Results indicated that A. succinogenes grown on CSAC could enhance the yield, productivity, and titre of succinic acid from OPF bagasse hydrolysate. The maximum yield and productivity obtained in this work were amounted to $0.9 \mathrm{~g} \mathrm{~g}^{-1}$ and $1.3 \mathrm{~g} \mathrm{~L} \mathrm{~L}^{-1} \mathrm{~h}^{-1}$, respectively. Cell-recycle repeated batch processes attested to the strong mechanical properties of CSAC, and its stability for prolonged operations. From an industrial perspective, the use of cell immobilisation adopting a costeffective and robust support will be advantageous for high utilization rates of lignocellulosic biomass. Thus, the waste disposal problems can be eliminated thereafter.

\section{Conflicts of interest}

The authors declare that they have no conflicts of interest.

\section{Acknowledgements}

The authors wish to thank the Ministry of Higher Education, Malaysia for financial support of this work (LRGS/2013/UKM$\mathrm{UKM} / \mathrm{PT} / 01$ ) on project entitled "Biochemical Platform for Conversion of Diversified Lignocellulosic Biomass to Priceless Precursor and Biobased Fine Chemicals".

\section{References}

1 T. Poulsen and R. Lema, Renewable Sustainable Energy Rev., 2017, 73, 758-771.

2 S. P. M. da Silva, A. M. da Costa Lopes, L. B. Roseiro and R. Bogel-Łukasik, RSC Adv., 2013, 3, 16040-16050.

3 H. Rabemanolontsoa and S. Saka, RSC Adv., 2013, 3, 39463956.

4 D. Salvachúa, A. Mohagheghi, H. Smith, M. F. A. Bradfield, W. Nicol, B. A. Black, M. J. Biddy, N. Dowe and G. T. Beckham, Biotechnol. Biofuels, 2016, 9, 28.

5 X. Shi, Y. Chen, H. Ren, D. Liu, T. Zhao, N. Zhao and H. Ying, Bioresour. Technol., 2014, 174, 190-197.

6 E. R. Borges and N. Pereira, J. Ind. Microbiol. Biotechnol., 2011, 38, 1001-1011.

7 S. A. Pasma, R. Daik and M. Y. Maskat, AIP Conf. Proc., 2013, 1571, 753-759.

8 D. Y. Kim, S. C. Yim, P. C. Lee, W. G. Lee, S. Y. Lee and H. N. Chang, Enzyme Microb. Technol., 2004, 35, 648-653.

9 A. A. I. Luthfi, J. M. Jahim, S. Harun, J. P. Tan and A. W. Mohammad, Process Biochem., 2016, 51, 1527-1537.

10 J. P. Tan, J. M. Jahim, S. Harun, T. Y. Wu and T. Mumtaz, Int. J. Hydrogen Energy, 2016, 41, 4896-4906.

11 J. N. Putro, F. E. Soetaredjo, S.-Y. Lin, Y.-H. Ju and S. Ismadji, RSC Adv. , 2016, 6, 46834-46852.

12 S. H. Shuit, K. T. Tan, K. T. Lee and A. Kamaruddin, Energy, 2009, 34, 1225-1235.
13 J. H. Ahn, Y.-S. Jang and S. Y. Lee, Curr. Opin. Biotechnol., 2016, 42, 54-66.

14 A. A. I. Luthfi, S. F. A. Manaf, R. M. Illias, S. Harun, A. W. Mohammad and J. M. Jahim, Appl. Microbiol. Biotechnol., 2017, 101, 3055-3075.

15 Y. P. Liu, P. Zheng, Z. H. Sun, Y. Ni, J. J. Dong and P. Wei, J. Chem. Technol. Biotechnol., 2008, 83, 722-729.

16 H. G. Brink and W. Nicol, Microb. Cell Fact., 2014, 13, 1-12. 17 Y. Vervoort, A. G. Linares, M. Roncoroni, C. Liu, J. Steensels and K. J. Verstrepen, Curr. Opin. Biotechnol., 2017, 46, 120125.

18 C. Wittmann, Industrial Biotechnology: Products and Processes, John Wiley \& Sons, 2017.

19 S. E. Urbance, A. L. Pometto 3rd, A. A. Dispirito and Y. Denli, Appl. Microbiol. Biotechnol., 2004, 65, 664-670.

20 A. I. Galaction, R. Rotaru, L. Kloetzer, A. Vlysidis, C. Webb, M. Turnea and D. Cascaval, J. Microbiol. Biotechnol., 2011, 21, 1257-1263.

21 R. I. Corona-Gonzalez, R. Miramontes-Murillo, E. ArriolaGuevara, G. Guatemala-Morales, G. Toriz and C. PelayoOrtiz, Bioresour. Technol., 2014, 164, 113-118.

22 N. S. Jamali, J. M. Jahim, W. N. R. W. Isahak and P. M. Abdul, Energy Convers. Manage., 2017, 141, 354-366.

$23 \mathrm{~V}$. Nedovic and R. Willaert, Fundamentals of cell immobilisation biotechnology, Springer Science \& Business Media, 2013.

24 W. Zhuang, X. Liu, J. Yang, J. Wu, J. Zhou, Y. Chen, D. Liu and H. Ying, Microb. Biotechnol., 2017, 10, 502-512.

25 S. Babel and T. A. Kurniawan, Chemosphere, 2004, 54, 951967.

26 E. Budi, H. Nasbey, B. Yuniarti, Y. Nurmayatri, J. Fahdiana and A. Budi, AIP Conf. Proc., 2014, 130-133.

27 G. Vázquez, R. Alonso, S. Freire, J. González-Álvarez and G. Antorrena, J. Hazard. Mater., 2006, 133, 61-67.

28 C. P. Dwivedi, J. Sahu, C. Mohanty, B. R. Mohan and B. Meikap, J. Hazard. Mater., 2008, 156, 596-603.

29 N. Singh and C. Balomajumder, J. Environ. Chem. Eng., 2016, 4, 1604-1614.

30 A. S. da Costa Lopes, S. M. L. de Carvalho, D. d. S. B. Brasil, R. de Alcântara Mendes and M. O. Lima, Am. J. Anal. Chem., 2015, 6, 528.

31 D. Jenkins, Water Waste Treat. J., 1962, 9, 66.

32 J. P. Tan, J. M. Jahim, T. Y. Wu, S. Harun, B. H. Kim and A. W. Mohammad, Ind. Eng. Chem. Res., 2014, 53, 1612316134.

33 S. Y. Chen, Y. H. Wei and J. S. Chang, Appl. Microbiol. Biotechnol., 2007, 76, 67-74.

34 P. C. Chen, P. Zheng, X. Y. Ye and F. Ji, Enzyme Microb. Technol., 2017, 98, 34-42.

35 A. P. H. Association, A. W. W. Association, W. P. C. Federation and W. E. Federation, Standard methods for the examination of water and wastewater, American Public Health Association, 1915.

36 N. S. Jamali, J. Md Jahim and W. N. R. Wan Isahak, Int. J. Hydrogen Energy, 2016, 41, 21617-21627.

37 H. Liu and H. H. Fang, J. Biotechnol., 2002, 95, 249-256. 
38 E. Fournier, Curr. Protoc. Food Analyt. Chem., 2001, E1.1.1E1.1.8.

39 N. J. Kruger, Protein Protoc. Handb., 2009, 17-24.

40 P. M. Abdul, S. Harun, M. J. Jahim, M. Markom and O. Hassan, J. Sci. Technol., 2011, 49, 599-604.

41 N. A. Lutpi, J. M. Jahim, T. Mumtaz, P. M. Abdul and M. T. Mohd Nor, RSC Adv., 2015, 5, 19382-19392.

42 R. Vichuviwat, A. Boonsombuti, A. Luengnaruemitchai and S. Wongkasemjit, Bioresour. Technol., 2014, 172, 76-82.

43 M. O. Ilomuanya, B. Nashiru, N. D. Ifudu and C. I. Igwilo, Journal of Microscopy and Ultrastructure, 2017, 5, 32-38.

44 H. C. Flemming, T. R. Neu and D. J. Wozniak, J. Bacteriol., 2007, 189, 7945-7947.

$45 \mathrm{H}$. Barnes, Oceanography and marine biology, CRC Press, 2003.

46 S. Wuertz, P. L. Bishop and P. A. Wilderer, Biofilms in wastewater treatment, IWA Publishing, 2003.

47 Y. Zhang, F. Wang, X. Zhu, J. Zeng, Q. Zhao and X. Jiang, Bioresour. Technol., 2015, 193, 274-280.

48 T. More, J. Yadav, S. Yan, R. Tyagi and R. Surampalli, J. Environ. Manage., 2014, 144, 1-25.

49 J. Zeng, J.-M. Gao, Y.-P. Chen, P. Yan, Y. Dong, Y. Shen, J.-S. Guo, N. Zeng and P. Zhang, Sci. Rep., 2016, 6, 26721.

50 T. R. Garrett, M. Bhakoo and Z. Zhang, Prog. Nat. Sci., 2008, 18, 1049-1056.
51 L. Li, S. Liu and J. Liu, J. Hazard. Mater., 2011, 192, 683-690. 52 E. Wolak, E. Vogt and J. Szczurowski, E3S Web Conf., 2017, 14, 02033.

53 A. Iyer, K. Mody and B. Jha, Indian J. Exp. Biol., 2005, 43, 467471.

54 Z. P. Zhang, K. Y. Show, J. H. Tay, D. T. Liang, D. J. Lee and W. J. Jiang, Biotechnol. Bioeng., 2007, 96, 1040-1050.

55 C. Wang, Q. Li, D. Wang and J. Xing, Process Biochem., 2014, 49, 1245-1250.

56 M. V. Guettler, D. Rumler and M. K. Jain, Int. J. Syst. Bacteriol., 1999, 49, 207-216.

57 J. B. McKinlay, Y. Shachar-Hill, J. G. Zeikus and C. Vieille, Metab. Eng., 2007, 9, 177-192.

58 P. Zheng, J. J. Dong, Z. H. Sun, Y. Ni and L. Fang, Bioresour. Technol., 2009, 100, 2425-2429.

59 M. Alexandri, H. Papapostolou, L. Stragier, W. Verstraete, S. Papanikolaou and A. A. Koutinas, Bioresour. Technol., 2017, 238, 214-222.

60 B. Litsanov, M. Brocker and M. Bott, Appl. Environ. Microbiol., 2012, 78, 3325-3337.

61 R. I. Corona-González, K. M. Varela-Almanza, E. ArriolaGuevara, Á. de Jesús Martínez-Gómez, C. Pelayo-Ortiz and G. Toriz, Bioresour. Technol., 2016, 205, 15-23.

62 Y. J. Wee, J. S. Yun, K. H. Kang and H. W. Ryu, Appl. Biochem. Biotechnol., 2002, 98, 1093. 